\title{
Peers Teenagers Healthy Prevent Drug Abuse on Teenagers in School
}

\author{
Roma Tao Toba MR ${ }^{1}$, Elly Nurachmah ${ }^{2}$, Astuti Yuni Nursasi ${ }^{3}$, Tris Eryando ${ }^{4}$, Arman \\ Harahap 5 \\ ${ }^{I}$ Faculty of Health Sciences, Universitas Borobudur, Indonesia \\ ${ }^{2,3}$ Faculty of Nursing, Universitas Indonesia \\ ${ }^{4}$ Faculty of Public Health, Universitas Indonesia \\ ${ }^{5}$ Faculty of Teacher Training and Education, Univeritas Labuhanbatu, Indonesia \\ romaregar@gmail.com
}

\section{Abstract}

Adolescence is a period of transition from children to adult. The young undergo metamorphosis physical impact for the progress of the psychological result in adolescents at risk of experiencing health problems. A problem that is often experienced in adolescents between the other Drug abuse. Research objectives to get an overview of the effectiveness of Peer Teenagers Healthy (TEBARS) in the prevention of Drug abuse in adolescents in school, using a quasi-experiment, the sample obtained by random. The results illustrate Peers Teenagers Healthy is quite effective in preventing Drug abuse on teenagers in school, lack of knowledge of the average of 28.83 be 27.59, SD 1.558, $p=0.000$, risky behavior average of 49.23 be 43.32, SD 4.365, $p=0.000$. The average appearance Peers Teenagers Healthy before the intervention of 5.3 points increased to 7.8 point. The results of this study are expected to be implemented in schools and developed and fostered more to prevent Drug abuse.
Keywords

addescence; peer

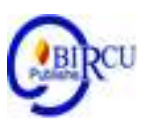

\section{Introduction}

Adolescence is a period of transition from childhood to young adulthood. Adolescence is a phase of life are important in health to be an adult which future set (Sawyer et al., 2012). Teens in search of identity tend to accept the challenge or try to do something without a prior consideration so that it can encourage the youth towards the risky behavior that can cause a variety of problems that will affect his health. Drug abuse in adolescents is a public health problem that is quite important, other issues in adolescents is school failure, delinquency, motor vehicle accident, arrest and detention, as well as an increased risk of HIV and diseases of other physical (Liddle et al., 2001).

The high level of drug abuse on youth has become a serious public health problem in all over the world. In the U.S. 75,6\% for youth under the age of 18 years have admitted using addictive substances (like cigarette, alcohol, marijuana and/or cocaine) at least once (Wang et al., 2016). In Indonesia, the numbers of drug abuse in 2017 as much as 3.376.115 people in the age range of 10-59 years, while the numbers of Drug abuse among students in 2018 reached 2.29 million people. This figure has increased by $24 \%-28 \%$ and most of the users are children and adolescents in the age range of 15-35 years or generations milineal. (BNN, 2019) 
Drug abuse and other drugs during adolescence and early adulthood still be a serious public health problem. Drug abuse creates a burden of socio-economic substantive in the country. Drug abuse and addiction increase the cost of treatment, a crime related to drugs and unemployment. (Hall et al., 2010). Narcotics abuse is an endemic disease in society, especially in people who do not have strong faith (Tumanggor et al, 2019). The result that occurs in the family, namely the problem of social, financial, relationship, psychological, physical or legal. Drug use by parents have a devastating impact, not only on the health and behavior of the parents, but also on the lives of children (Cousins \& Milner, 2006)

Due to Drug Abuse not only cause deviations in behavior that violates the norms prevailing in society, but also triggered a major problem that gives a negative effect on the function of the organs of the body (Syarief, 2008). Banks and Waller (1983; in the Hawari, 2001) declared Drug abuse lead to complications of medical specialized respiratory disorders, namely pulmonary edema and disorders of the lever.

Drug abuse also cause losses in the economic field. The study of the loss of economic cost and social impact of the Drug has ever been conducted in different countries with different methods and approaches. America is experiencing economic losses amounted to $\$ 180.8$ billion and in Indonesia a similar survey conducted in 2004 and 2008. The results tend to increase the losses of the economic costs due to Drug abuse from the Rp.23 triyun to Rp.32 trillion in 2008 and 2011 amounted to Rp.48,2 trillion. (BNN, 2011).

The economic and social impacts of Drug abuse is very large, make the prevention and Drug prevention as an effort that is very urgent in almost all countries. One of the prevention of Drug abuse has been committed by the Indonesian government through the Ministry of Health with the issuance of the policy which is in the form of PKPR (Health Care Service Teen). The results of interviews with program implementers PKPR Health Department obtained information that not all schools can be implemented program PKPR and training because of limited funds and human resources to carry out such activities. This is supported by the results of the research Santoso (2010) which states the role of the counselor conducted by students not optimal in discussion with peers, students have not been able to give a response to feedback when it gets questions from peers, students tend to just share the experience. Based on this the researchers concluded efforts to control health of adolescents in JUNIOR high school/MTs/sederajat in particular the prevention of Drug abuse through peer counselor not give significant results. The reason is this that drives the researcher to intervene Peers Teenagers Healthy (TEBARS) in preventing Drug abuse on teenagers in school.

\section{Research Methods}

The method used is quasi experiment with the calculation of a large sample based on the total number of students number of 1165 people, then counted the number of samples in the following way (Lameshow, 1997):

$$
\mathrm{n}=\frac{\mathrm{z}^{2}(1-\alpha / 2) \times \mathrm{p}(1-\mathrm{p}) \mathrm{N}}{\mathrm{d}^{2}(\mathrm{~N}-1)+\mathrm{z}^{2}(1-\alpha / 2) \mathrm{p}(1-\mathrm{p})}
$$

Large sample obtained 83, in anticipation of the drop out, the authors perform correction of the sample have been calculated. The formula used according to Sastroasmoro (2002) is: 


$$
\mathrm{n}^{*}=\mathrm{n} /(1-\mathrm{f})=83 /(1-0,1)=83 / 0,9=92
$$

where: $\mathrm{n}^{*}=$ large sample after correction

$\mathrm{f}=$ estimate of the proportion of drop out $=10 \%$

Having obtained the number of samples and anticipate droup out then the total number of samples to be 92 . Furthermore, the authors identify the sample with the teacher steering committee, it was decided samples were taken based on the cluster is a class 7 (46 samples) and class 8 (46 samples). Data collection was conducted by distributing questionnaires, interviews, windshield survey, focus group discussion (FGD) as a source of primary data, while secondary data sources obtained from documentation of the department of health, health center, district, village, and school.

Analysis of the data used in this research is univariate and bivariate. Univariate analysis aims to explain or describe the characteristics of each research variable. Bivariate analysis was done against two variables and allegedly had a relationship or correlated. Statistical analysis used for categorical data with numeric is with the test, using the degree of confidence of $95 \%$ or significance level of $5 \%$, said to be meaningful if $p<0.05$.

The training material provided regarding the growth of teenagers, the dangers of smoking/DRUG use, free sex, HIV/AIDS, hepatitis, clean and healthy behavior (PHBS), communication engineering assertive and exercise refuse the invitation. Learning method that is used with the learning of participatory peer group, among others, the visualization in participatory program (visualization in participatory programmes/VIPP), brainstorming (brainstorming), role play (role-play), game therapy/game, case study, discussion, lecture method, demonstration method, small group studies (buzz group), and simulation methods. This was followed by a teenager with enthusiasm because of the available reward for the group that actively participate.

\section{Results and Discussion}

\subsection{Results}

The results of the data collection conducted by researchers of 92 JUNIOR high school students before the intervention, found that $69 \%$ of students have less knowledge about Drugs, $35 \%$ of students have smoking behavior, $49 \%$ of smoking behavior influenced by peers, $51 \%$ of students have coping positive, $55 \%$ of students requires knowledge about life skills (life skills), 50\% of students stated the efforts of the school in the prevention of Drug-positive, $32 \%$ of students expressed the government's efforts in the prevention of Drug positive, 53\% of students stated the efforts of health services towards prevention of DRUG abuse positive, 38\% of students expressed the attitude of the community towards the prevention of DRUG abuse positive, $43 \%$ of students have positive behavior in the family.

Results after the intervention, Peer Teenagers Healthy obtained data such as contained in table 1 and table 2.

Table 1. Distribution of the Average of Students ' Knowledge about Drugs

\begin{tabular}{lccccc}
\hline Variable & Mean & SD & SE & P value & N \\
\hline Peers Teenagers Healthy: & & & & & \\
Before & 28,83 & 2,020 & 0,229 & 0,000 & 92 \\
After & 27,59 & 2,288 & 0,202 & & \\
\end{tabular}


Table 2. The distribution of the Average Behavior of Students against Drugs

\begin{tabular}{lccccc}
\hline Variable & Mean & SD & SE & P value & N \\
\hline Peers Teenagers Healthy: & & & & & \\
Before & 49,23 & 8,294 & 0,829 & 0,000 & 92 \\
After & 43,32 & 5,986 & 0,599 & & \\
\hline
\end{tabular}

\subsection{Discussion}

The implementation of Peer Teenagers Healthy (TEBARS) using three strategic approaches to community intervention, namely health education, group process, and empowerment. This is consistent with Anderson and McFarlane, (2004) which states health education, group process, empowerment, and partnership in addressing the issue of Drug abuse in adolescents.

The strategy of health education is an effort of health promotion. The efforts of health promotion is very important because it is the efforts of primary prevention against the risk of Drug abuse prevention in school (Stanhope \& Lancaster, 2004), and through health education can improve the intelligence of the youth/students. Peer relations, school environment, sociocultural norms and the influence of the media have an empirical relationship with the development and maintenance of drug abuse teenagers (Liddle et al., 2001). The role of peer educators conducted by the students quite optimal in discussion with peers, students are able to give ideas/feedback response in the form of a parable or question stimulus when the discussion occurred, for example when the peer to peer either in class or in small groups.

The results of the author's observations of the school environment is very good for the educational process, but important to also experience changes in the school system in order to further improve the function of school for students, teachers and the community. Policy changes can be analyzed at the level of intraorganisasi (Allison, 1971; Bolman \& Deal, 1979; William \&Elmore, 1976; Bardach, 1977; Hargrove, 1975 in Green \& Kreuter, 2000). Levels of analysis in organizations is very important in the efforts of health promotion because of the many programs and policies are needed in changing the lifestyle and environment that is controlled by the many organizations that are outside the health sector (Green \& Kreuter, 2000).

Peers Teenagers Healthy (TEBARS) is modofikasi of peer educator who has performed in several Countries in the prevention of Drug abuse. The results of the research Goren (2006) mentions that the peer educator is effective in the prevention of Drug abuse and has been applied in Canada, USA, Australia and Zambia. Peer educator used as the main intervention in the group of adolescents in the prevention of Drug abuse because at the stage of adolescence the relationship between among my peers is important because adolescents are more familiar with the peers and can be fused in the group in terms of how to dress, get along, style of talking, music, and interests (Mira, 2005). The results of the research of Anthony et al (2009) properties of ductile, high intelligence \& temperament positive give teens the ability to triumph over adversity. If teens have the correct understanding then will be protected from Drug abuse.

The behavior of a mutually agreed upon and carried out by teen then got reinforcement positive/reward, but if not implemented then the teen was given a sentence like add your current home activities to help parents complete the activities of the household. Stuart (2009) mention of behavior modification with the granting of awards is carried out simultaneously have a goal so that there is a change in behavior. The behavior of adolescents in dealing with peers or people around him very much influenced by the $\mathrm{mood} / \mathrm{mood}$ It is supported by Sprinthall and Collins (1995) which states that the deviation 
of behavior appears due to the development of a value that is not adequate in adolescents. This condition is in line with the growth and development of adolescents, so that the deviation of behavior can be caused because of the unfulfilled task of adolescent development.

Interventions carried out by the methods of health education (KIE), coaching, guidance and conseling in the development and life skills of youth (responsibility, selfconfidence, and resisting calls for assertive), and the development of the skills of parents in communicating effectively provide a positive picture qualitatively.

\section{Conclusion}

Peers Teenagers Healthy (TEBARS) is a modification of the peer educator through the empowerment of youth/students in the setting of the school who were given the knowledge and skills about Drug to enhance the capabilities of a teenager in school in an effort to prevent Drug abuse.

Increase students ' knowledge about Drugs that before the intervention less knowledge of $100 \%$ after the intervention to $68 \%$ of the knowledge of good. the average risk of adolescent Drug abuse decreased 5.91. The average appearance of the members of the TEBARS/peer educator is increased by 2, 5 point and look more confident.

Parenting families with children age teenager becomes effective with the presence of behavior change in adolescents become more positive approach to family therapy, coaching, and counseling. Peer educator/Peers Teenagers Healthy (TEBARS) is the empowerment of the youth/students in the setting of the school who were given the knowledge and skills about the risk of misuse of the DRUG to improve the ability to aggregate teen at the school in an effort to prevent the risk of DRUG abuse

Suggestions researchers for further research is to examine the effectiveness and efficiency of the Peer Teenagers Healthy (TEBARS) in preventing health problems in adolescents, especially Drug abuse prevention school-based periodic and sustainable.

\section{References}

Anthony, Elizabeth et al. (2009). Development of a Risk and Resilience-Based Out-ofSchool Time Program for Children and Youths.

Anderson, ET. \& McFarlane,J (2000). Community as partner : thepry and Practice in nursing. Philadel[hia : lippincot

Badan Narkotika Nasional Republik Indonesia. (2011). Jakarta: Puslitbang BNN

Badan Narkotika Nasional Republik Indonesia. (2019). Jakarta: Puslitbang BNN

Goren, Netzach \& Wright Karen (2006). Peer education as a drug prevention strategy. Diakses dari www.druginfo.adf.org.au

Hawari, Dadang. (2001). Penyalahgunaan dan Ketergantungan NAZA, Jakarta : Fakultas Kedokteran Universitas Indonesia

Hitchcock,JE., Scubert, PE., \& Thomas, SA (1999). Community Health Nursing : Caring in action. USA : Delmar Publisher

Santoso,Budi (2009). Pengalaman Mantan Pengguna dalam Penyalahgunaan NAPZA Suntik di kota Palembang: Thesis Program Magister Ilmu Keperawatan FIK-UI : tidak dipublikasikan

Cousins, W., \& Milner, S. (2006). Drug abuse and parenting: The impact on young children in the social care system in Northern Ireland. Journal of Aplied Social Studie, 7(1), 95-108. 
Green, L. W., \& Kreuter, M. W. (2000). Erratum: Commentary on the emerging Guide to Community Preventive Services from a health promotion perspective (American Journal of Preventive Medicine (January 2000) 18:15)). American Journal of Preventive Medicine, 18(3), 269.

Hall, P. B., Hawkinberry, D., \& Moyers-Scott, P. (2010). Prescription drug abuse \& addiction: past, present and future: the paradigm for an epidemic. The West Virginia Medical Journal, 106(4 Spec No), 26-32.

Liddle, H. A., Dakof, G. A., Parker, K., Diamond, G. S., Barrett, K., \& Tejeda, M. (2001). Multidimensional family therapy for adolescent drug abuse: results of a randomized clinical trial. The American Journal of Drug and Alcohol Abuse, 27(4), 651-688. https://doi.org/http://dx.doi.org/10.1081/ADA-100107661

Sawyer, S. M., Afifi, R. A., Bearinger, L. H., Blakemore, S. J., Dick, B., Ezeh, A. C., \& Patton, G. C. (2012). Adolescence: A foundation for future health. The Lancet, 379(9826), 1630-1640. https://doi.org/10.1016/S0140-6736(12)60072-5

Tumanggor, F., et al. (2019). Handling of Narcotics Child Victims in Child Special Coaching Institutions Class I Tanjung Gusta, Medan. Budapest International Research and Critics Institute-Journal (BIRCI-Journal). P. 50-55.

Wang, L. J., Lu, S. F., Chong, M. Y., Chou, W. J., Hsieh, Y. L., Tsai, T. N., Chen, C., \& Lee, Y. H. (2016). A family-oriented therapy program for youths with substance abuse: Long-term outcomes related to relapse and academic or social status. Neuropsychiatric Disease and Treatment, 12, 699-706. https://doi.org/10.2147/NDT.S105199 